\title{
IbM PENGRAJIN ROTAN DI KELURAHAN LEMBO
}

\author{
Fatmawati Andi Mappasere1), Naidah Hus ein ${ }^{2)}$ \\ ${ }^{1}$ Fakultas Ilmu Sosial dan Ilmu Politik, Unismuh Makassar \\ email: fatmamappasere@gmail.com \\ ${ }^{2}$ Fakultas Ekonomi dan Bisnis, Unismuh Makassar \\ email: naidahusain@yahoo.com
}

\begin{abstract}
Rotan merupakan industri kreatif yang banyak ditekuni secara turun temurun oleh masyarakat di Kelurahan Lembo Kota Makassar. Proses produksi dilakukan dengan meng gunakan alat-alat yang sederhana dengan mengandalkan keterampilan tangan para pekerja. Dua kelompok mitra (MAWAR dan ANGGREK) sebagai kelompok sasaran program IbM ini mengalami berbagai kendala dalam mengembangkan usahanya, seperti: kurangnya modal, kurangnya keterampilan dan lemahnya pemasaran. Program IbM dilakukan dengan tujuan: 1) meningkatkan pemahaman mitra tentang manajemen organisasi; 2) meningkatkan keterampilan mitra dalam mengelola administrasi keuangan; dan 3) meningkatkan kemampuan mitra dalam produksi kreatif dan pemasaran. Pendekatan yang ditawarkan untuk mencapai tujuan ini adalah model pemberdayaan melalui penyuluhan, pelatihan dan pendampingan. Pelaksanaan kegiatan meliputi beberapa tahap, antara lain: 1) persiapan, 2) penilaian, 3) rencana aksi, 4) implementasi, dan 5) evaluasi.
\end{abstract}

Keywords: Industri kreatif rotan dan Pemberdayaan 


\section{PENDAHULUAN}

Kerajinan rotan merupakan industri kreatif yang memanfaatkan bahan dasar dari rotan yang banyak ditekuni oleh masyarakat di Kelurahan Lembo Kecamatan Tallo Kota Makassar. Seperti kebanyakan industri kecil lainnya, industri kerajinan rotan dari kelompok pengrajin rotan ini belum dikelola secara profesional. Hal ini tentu tak lepas dari banyaknya permasalahan yang dihadapi industri kecil pada umumnya. Industri rotan di sini diusahakan dalam bentuk industri kerajinan tangan yang dikelola secara tradisional. Proses produksi dikerjakan dengan menggunakan alatalat yang sangat sederhana dengan mengandalkan keterampilan tangan para pekerjanya.

Dua kelompok mitra (MAWAR dan ANGGREK) sebagai kelompok sasaran dari program IbM ini mengalami berbagai kendala antara lain: permodalan, keterampilan dan pemasaran. Walaupun kegiatan kelompok ini sudah berjalan dan memberikan manfaat bagi para anggotanya, namun belum berjalan optimal disebabkan masih kurangnya pengetahuan dan keterampilan dalam bidang manajeman organisasi dan administrasi keuangan. Pencatatan pembukuan masih dilakukan secara sangat sederhana. Kelemahan lainnya adalah produk yang dihasilkan terkesan monoton (kurang kreatifitas atau diversifikasi produk). Dari segi pemasaran, menerima pesanan dari langganannya dan hanya mengandalkan promosi dari mulut ke mulut. Dengan kualitas yang seperti itu penjualan hasil industri kerajinan rotan, hanya mampu menembus pasar lokal saja. Dengan demikian, Mitra ini perlu dibantu dalam bidang manajemen usaha untuk pengembangan jaringan pemasaran, serta teknik pencatatan administrasi keuangan yang baik. Melalui progam IbM ini telah dilakukan pelatihan dan pendampingan kemampuan manajerial seperti pembenahan pembukuan, perluasan pemasaran dan diversifikasi desain. Diharapkan ke dua Mitra ini akan mampu memasarkan produk secara mandiri dan mampu mengembangkan produk dengan desain-desain yang lebih menarik dan harga yang bersaing.

\section{KAJIAN LITERATUR DAN PEGEMBANGAN HIPOTESIS}

Keranjang rotan merupakan salah satu kelompok dari barang kerajinan. Dalam pembuatannya memerlukan ketrampilan, ketekunan, dan kreativitas dari pembuatnya. Sehingga kerajinan rotan dapat dimasukkan ke dalam sektor industri kreatif, dimana masyarakat setiap harinya terlibat dalam situasi dan aktivitas membuat berbagai barang kerajinan berbahan dasar rotan. Seperti yang diungkapkan oleh Mari Eka Pangestu (2007), bahwa yang termasuk sektor industri kreatif beberapa diantaranya adalah; periklanan, pasar seni, kerajinan, dan desain.

\section{METODE}

Berdasarkanbeberapa permasalahan mitra yang telah dirumuskan sebelumnya, maka pendekatan yang ditawarkan bagi realisasi program IbM ini adalah model pemberdayaan dengan langkah-langkah sebagai berikut : 1) Tahap Persiapan; 2) Tahap Assesment; 3) Tahap Perencanaan Alternatif Kegiatan; 4) Tahap Formulasi Rencana Aksi; 5) Tahap Pelaksanaan Kegiatan; 6) Tahap Evaluasi; serta

7) Tahap Terminasi. (Isbandi, 2008)

Program IbM ini dilaksanakan sebagai upaya pemberdayaan kelompok pengrajin rotan melalui kegiatan pelatihan kewirausahaan yang menitikberatkan kepada pengembangan usaha. Metode pelaksanaan program yang akan dilakukan adalah: (1) pelatihan manajemen organisasi; (2) Pelatihan produksi; (3) pelatihan administrasi keuangan; dan (4) pendampingan. Semua metode ini merupakan satu kesatuan.

\section{HASIL DAN PEMBAHASAN}

Kegiatan yang sudah dilakukan beserta hasil yang dicapai sebagai berikut:

\subsection{Persiapan}

Tim melakukan persiapan melalui koordinasi dalam tiga kali rapat atau pertemuan. Dalam persiapan ini dibahas tentang materi kegiatan, menentukan narasumber, waktu kegiatan, dan pembagian tugas panitia pelaksana kegiatan di lapangan. Dalam pertemuan koordinasi ini, ketua tim pengabdi melakukan koordinasi dengan anggota tim untuk melaksanakan rangkaian kegiatan pengabdian. Koordinasi dilaksanakan pada bulan April-Juli 2016 dalam rangka melaksanakan pelatihan manajemen 
organisasi dan pembukuan keuangan dan pelatihan aneka kreasi souvenir dari rotan.

Langkah berikutnya adalah mengurus surat izin pelaksanaan pengabdian pada pemerintah setempat yaitu Pemerintah Kelurahan Lembo. Proses administrasi yang tim pelaksana program IbM tempuh adalah berkoordinasi dengan Lembaga Penelitian, Pengembangan dan Pengabdian Masyarakat (LP3M) Unismuh Makassar untuk meminta surat pengantar kegiatan pengabdian dalam program IbM dengan judul "IbM Kelompok Pengrajin Rotan di Kelurahan Lembo. Surat pengantar kemudian dibawa di Kantor Badan Koordinasi Penanaman Modal Daerah (BKPMD) Propinsi Sulawesi Selatan. Besoknya, surat pengantar dari BKPMD dibawa di Kantor Badan Kesatuan Bangsa dan Politik (Kesbangpol) Kota Makassar. Hasilnya Selanjutnya dibawa ke Kantor Kecamatan Tallo. Selanjutnya dibawa ke Kantor Kelurahan Lembo dimana lokasi kegiatan kedua mitra berada di kelurahan tersebut. Di Kantor Kelurahan Lembo, Tim IbM meminta izin dan sekaligus mensosialisasikan maksud dan tujuan dari program ini pada aparat kelurahan.

\subsection{Sosialisasi Kegiatan Program IbM}

Setelah alur birokrasi dilewati, maka Tim program IbM melakukan pertemuan dengan kedua kelompok mitra dan mensosialisasikan maksud dan tujuan dari program IbM ini. Kedua kelompok mitra menyambut dengan hangat dan pada prinsipnya bersedia bekerja sama dengan tim IbM. Dengan adanya tanggapan positif dari pihak kelompok mitra kegiatan IbM bisa berjalan lancar, semua program dapat berjalan sesuai dengan waktu yang telah ditetapkan.

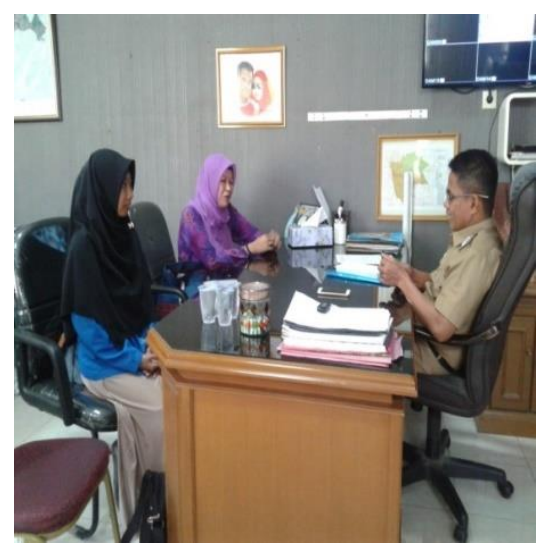

Ganbar 1. Sosialisasi pada aparat kelurahan

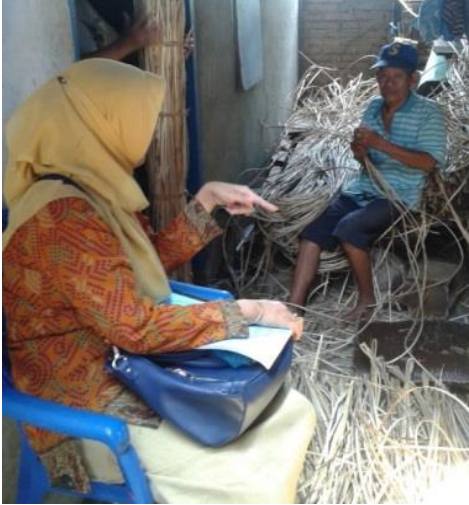

Gambar 2. Sosialisasi pada mitra

\subsection{Pelaksanaan Kegiatan}

Langkah-langkah pelaksanaan kegiatan pengabdian adalah sebagai berikut.

a. Pelatihan Manajemen Usaha. Pelatihan ini bertujuan untuk :

1. Meningkatkan pengetahuan dan jiwa wirausaha para pengrajin rotan;

2. Meningkatkan kemampuan mitra mengelola organisasi

3. Meningkatkan pengetahuan dan keterampilan mitra melakukan administrasi keuangan dan pembukuan usaha

4. Meningkatkan pengetahuan dan kemampuan manajemen usaha terutama manajemen pemasaran dalam rangka meningkatkan pendapatan usaha.



Gambar 3.Pelatihan Manajemen Organisasi

\subsection{Penyerahan Bantuan Sarana Produksi} Penyerahan bantuan sarana produksi diberikan kepada mitra dalam rangka menunjang pelaksanaan kegiatan pelatihan desain industri kerajinan yang lebih beraneka ragam dan kreatif. Peralatan yang diberikan kepada mitra 
berupa: kompor rotan, timbangan, cat pernis dan peralatan mewarnai produk, dan gunting rotan. Selain peralatan itu, mitra dibantu pula dalam pengadaan bahan baku kerajinan berupa rota. Pemberian bantuan rotan terdiri atas 3 jenis yaitu rotan fitrit, rotan ulasan, rotan bundar dan rotan kulit.

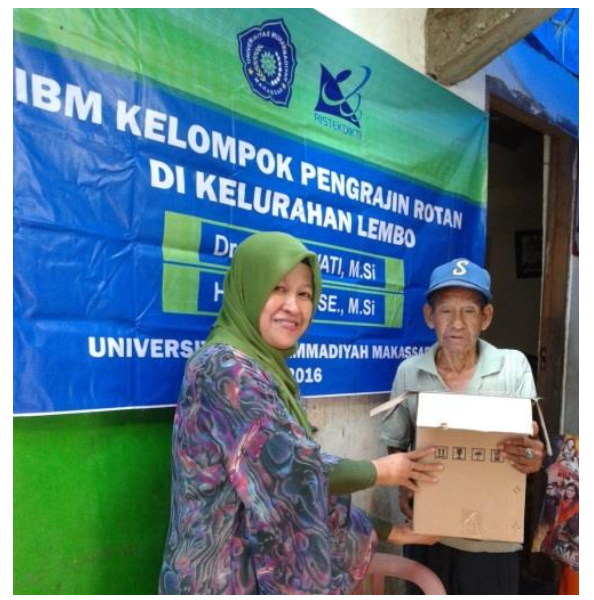

Gambar 4. Pemberian bantuan peralatan

\subsection{Pelatihan desain yang lebih kreatif}

Pelatihan ini diberikan kepada mitra dalam rangka mengatasi kemonotoman produksi dari mitra. Dengan adanya pelatihan ini menimbulkan kemampuan berkreasi sehingga terjadi diversifikasi produk.



Gambar 5. Kegiatan pelatihan

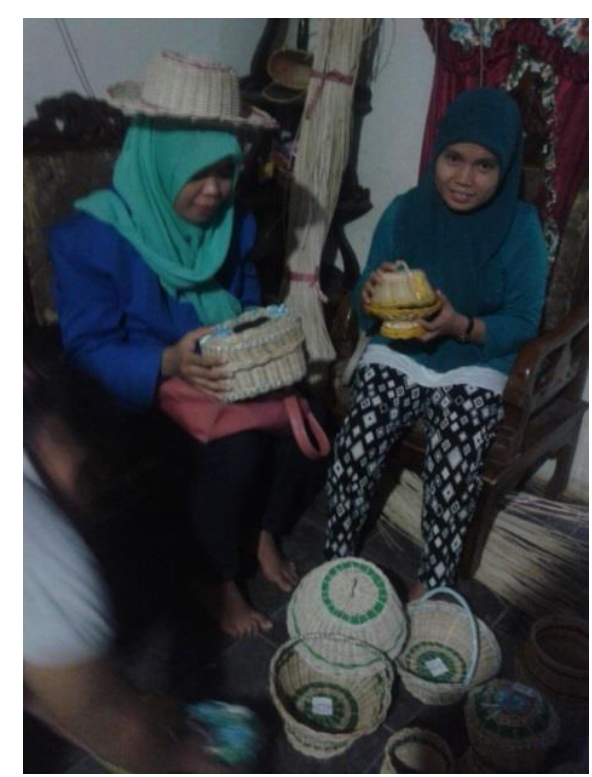

Gambar 6. Beberapa produk hasil dari kegiatan pelatihan

\section{KESIMPULAN DAN SARAN}

Program IbM yang dilakukan pada Mitra berupa pendampingan manajemen organisasi dan administrasi keuangan serta pelatihan desain produk kreatif berhasil meningkatkan kinerja organisasi kedua mitra berupa:

1. Administrasi keuangan telah dilakukan secara kontinu, sehingga aliran kas dana masuk dan keluar dapat terpantau serta modal dan laba dapat diketahui.

2. Kualitas produk ditingkatkan dengan menggunakan bahan baku dan peralatan yang lebih baik, serta desain produk yang lebih kreatif.

3. Pemasaran semakin luas dengan memperkenalkan produk mitra melalui pameran.

4. Perlu dukungan pemerintah dalam bentuk fasilitasi peralatan pengolahan rotan yang lebih modern.

\section{REFERENSI}

Hamid, Edy Suandi dan Susilo, Sri. Y. 2011. Strategi pengembangan usaha mikro kecil dan menengah di Provinsi Daerah Istimewa Yogyakarta. Jurnal Ekonomi Pembangunan,Vol.12, (no.1) : 44-55.

Isbandi R. Adi. 2008. Pemberdayaan, Pengembangan Masyarakat dan Intervensi Komunitas. Jakarta: Raja Grafindo Persada 
Kemendag RI. 2013. Pengembangan Produk Mebel Rotan Indonesia. Warta Ekspor: http://djpen.kemendag.go.id/

Longenecker. Justin. Dkk. 2003. Kewirausahaan Manajemen Usaha Kecil. Jakarta: Salemba Empat

Soetomo, 2010, Strategi-strategi Pembangunan Masyarakat. Yogjakarta: Pustaka Pelajar

Suharto, Edi. 2005. Membangun Masyarakat Memberdayakan Rakyat. Bandung: Refika Aditana 